\title{
100
}

\section{The public trust doctrine and sustainable development: An aspect of environmental law}

\author{
S S M De Silva \\ Department of Commerce, University of Sri Jayewardenepura, Sri Lanka
}

The objective of this study is to introduce the public trust doctrine and to examine its application in relation to sustainable development. To facilitate this study judgments of the superior courts of Sri Lanka, India, the United States and several other countries are referred to.

The international instruments relating to environment demonstrate the concern of the international community for a healthy environment for all life forms including human beings through sustainable development. Sustainable development according to Bruntland Report (1987) is the development that meets the needs of the present without compromising the ability of the future generations to meet their own needs. The public trust doctrine is an essential element of judicial process to facilitate towards sustainable development.

The public trust doctrine in essence means that powers vested in public authorities are not absolute or unfettered but are held in trust for the public, to be exercised for the purposes for which they have been conferred and that their exercise is subject to judicial review by reference to those purposes. Administrative acts and decisions contrary to the public trust doctrine and lor violative of human rights would be in excess or abuse of power and therefore void. The Court expressed the view that in such judicial review the historical English law limitations on prerogative writs are no longer applicable, because now Sri Lankan courts not courts of the Crown but are bound by the public trust doctrine and are subject to fundamental rights.

Undoubtedly the State has the right to exploit its own resources pursuant, however, to its own environmental and developmental policies and laws. Rational planning constitutes an essential tool for reconciling any conflict between the needs of development and the need to protect and improve the environment. Human beings are at the centre of concern for sustainable development. In order to achieve sustainable development, decision making process must also comply with public trust doctrine.

\section{1 \\ Community engagement in forest resource protection in Sri Lanka dry zone: A success story}

\author{
A Widanapathirana \\ Joseph Lane, Colombo 04
}

This paper describes the setting, the strategies utilized and the outcome of a pilot community forest protection project implemented in the Sri Lanka Dry Zone. The experiment was executed under a partnership between the Forest Department (FD) and the Sri Lanka Australia Natural Resource Management Project (SLANRMP) resourced by the Australian Aid International Development (AusAID). The purpose of the SLANRMP is to test approaches to community management of natural resources for poverty reduction. A degraded 150 ha forest patch known as Nikawekanda North West Dry Zone was selected. This forest has only about a third of its area under forest cover while the rest is occupied by grass as a result of burning. The forest fire has destroyed the trees and the vegetation every year over the past 2-3 decades. The remaining forest area is under severe threat. The tussock grass cover acts as a trigger to spread fire during the dry months.

Upon identification of the households which would directly benefit from a programme of effective protection of Nikawekanda, the project supported a series of participatory exercises involving both the community as well as the authorities. The process uncovered useful information such as sources of forest fire and the process of destruction, strategies to prevent fire, forest planting and management options, the community benefits from forest protection, community preparations, etc. among others. Subsequently, a strategic action plan prepared entirely through community participation focused not only on the forest management but also on other rural recources and livelihood activities. Small group

Proceedings of the International Foresiry and Environment Symposium 2006 of the

Department of Forestry and Environmental Science, University of Sri Jayewardenepura, Sri Lanka 